\title{
Corporate crisis management in Italy: execution, monitoring and performance analysis of recovery business and financial plans
}

\author{
Alberto Tron \\ Dipartimento di Economia e Management, \\ University of Pisa, \\ Pisa, Italy

\section{Giuseppe Valenza} \\ Dipartimento di Scienze Economiche, Aziendali e Statistiche, \\ University of Palermo, \\ Palermo, Italy \\ Email: giuseppe.valenza01@unipa.it
}

\author{
Andrea Caputo* \\ Lincoln International Business School, \\ University of Lincoln, \\ Lincoln LN6 7TS, UK \\ Email: acaputo@lincoln.ac.uk \\ *Corresponding author
}

\begin{abstract}
This paper presents a thorough investigation of how corporate crises are managed in the Italian context. It offers an investigation of the legal, accounting, finance and managerial aspects that are involved in the formal resolution of the crisis. The paper adopts a qualitative methodology consisting in a critical review of both the academic and the practical literature to present a systematic overview of how recovery plans are executed, monitored and their performance analysed. The paper presents important insights for researchers, practitioners, entrepreneurs and managers interested in crisis management.
\end{abstract}

Keywords: crisis management; Italy; restructuring; turnaround; monitoring; finance.

Reference to this paper should be made as follows: Tron, A., Valenza, G. and Caputo, A. (2018) 'Corporate crisis management in Italy: execution, monitoring and performance analysis of recovery business and financial plans', Int. J. Foresight and Innovation Policy, Vol. 13, Nos. 1/2, pp.114-135.

Biographical notes: Alberto Tron, a CPA and Auditor, is adjunct Professor of Auditing at the University of Pisa. He has authored several articles and books also at an international level. His main research sectors are finance, corporate crisis, turnaround and accounting. 
Giuseppe Valenza is Adjunct Professor of Business Administration at the University of Palermo. He received his $\mathrm{PhD}$ in Business Administration from the University Mediterranea of Reggio Calabria, in Italy. His main research expertise is related to financial accounting, accounting history, entrepreneurship, and strategic management.

Andrea Caputo is Reader in Entrepreneurship at the Lincoln International Business School (UK). He received his $\mathrm{PhD}$ in Management from the University of Rome 'Tor Vergata', in Italy. He has authored several international publications. His main research expertise is related to negotiation, decision-making, entrepreneurship and strategic management.

\section{Crisis management and the protection of a company's value}

Crisis situations can be defined as those in which companies lose one of the two fundamental equilibria in the business: the economic or the financial equilibrium.

The economic equilibrium is the ability to generate, in the medium-long term, a profitability for shareholders at least equal to the opportunity-cost of risk capital (cost of equity). Basically, this is the condition for creating value for shareholders. The investment made in the company increases in value when the expected returns are higher than those that could be obtained in alternative investments with the same degree of risk (fair remuneration). The economic equilibrium refers by definition to the medium-long term as it regards the firm's ability to produce fair remuneration (Rappaport, 1998; Morin and Jarrell, 2000; Botosan and Plumlee, 2002; Dallocchio and Salvi, 2004; Tron, 2013).

A company is in financial equilibrium when it has all or some of the following characteristics: it controls in the short term the gap between monetary income and expenditure; it shows a financial structure consistent with the strategy followed; it highlights a dynamics of working capital in line with the evolution of turnover; it has a correct relationship between operating income and financial charges; it has a correct ratio between the economic value of assets and the value of liabilities; it has an optimal relationship between total cash flow and business development; it presents a financial structure that maximises the value of the company; it has an optimal corporate capital structure (Titman and Wessels, 1988; Leland, 1994; Bolton and Scharfstein, 1996; Stohs and Mauer, 1996; Johnson, 1997; Donaldson, 2000; Ozkan, 2000; Pavarani, 2006; Lemmon et al., 2008; Von Thadden et al., 2010; Rauh and Sufi, 2010; Tiscini, 2014).

According to the document "Principi di redazione dei piani di risanamento (Principles for the preparation of recovery plans)" (hereinafter Principi ${ }^{1}$ ), the recovery plan is a document prepared by managers, with the support of specialised consultants, where strategic and operational actions (and the related economic and financial impacts) through which a company intends to defeat the crisis, are planned. The objective of a recovery plan is to restore the conditions of economic and financial equilibria (Principi, paragraph 1.2.1). Recovery plans are related to business recovery planning and business continuity planning (Phelps, 1986; Goh, 1996; Doughty, 2001; Botha and Von Solms, 2004; Cerullo and Cerullo, 2004; Alesi, 2008; Lindström et al., 2010; Sahebjamnia et al., 2015). 
A recovery plan necessarily implies the existence of a current state of crisis in a company and the following willingness by the entrepreneur or managers to restore the physiological conditions of the business of a healthy company (Dubrovski, 2004). The state of crisis may be due to the worsening of economic results and to a future insolvency. The state of crisis can be diagnosed through appropriate economic and financial monitoring (Principi, paragraph 1.2.3).

Managers must assess not only the intensity degree and the progress of the crisis situation, but also the relationships that the company holds with the external stakeholders (Williams and Olaniran, 1998; Sweetser and Metzgar, 2007; Acquier et al., 2008; González-Herrero and Smith, 2008, 2010; McDonald et al., 2010). In fact, such relationships determine the residual degree of autonomy of the company in managing the crisis and the recovery process. Relationships with stakeholders are of fundamental importance because they influences the divergence or alignment between their interests and the interests of the company (Tiscini, 2014).

The crisis situation must be managed through specific recovery strategies. In order to prevent the company's crisis from causing failure, it is necessary to proceed strategically by changing the organisational structure, also innovating the strategic formulas and the planning and control phases (Guatri, 1995; Preble, 1997; Marra, 1998; Kash and Darling, 1998; Sapriel, 2003; Galeotti, 2008; Osadchy and Akhmetshin, 2015).

The company's decline is generally caused by a negative performance in terms of value. The crisis derives from this negative performance and deeply involves the company in all its complexity. The crisis is a process that causes the inability of current and future income cash flows to face the fulfilment of the obligations assumed (Goode, 2011; Galeotti and Garzella, 2013).

In order to be able to effectively managed a crisis situation, it is necessary to respect the conditions of efficiency and equity, thus avoiding the failure of the company (Franceschi and Tedeschi, 2014). Efficiency conditions are respected when it is possible to maintain the maximum between the operating value and the liquidation value, avoiding unnecessary value destruction, with a view to minimising the costs (both direct and indirect) of bankruptcy. Equity conditions occur when the principles of the par condicio creditorum and the absolute priority rule are respected. These principles impose the same treatment of all creditors, in compliance with the order of ownership of legitimate causes of preemption (seniority). The requirement of equity, therefore, concerns the definition of the correct mechanisms for the participation in the operating or liquidation value of the company (Milman, 1991; Wood, 2007).

The tools for managing business crisis must be able to guarantee: the right of creditors to obtain repayment of their credits; the interest of many stakeholders (especially employees); the interest of the community in relation to a correct allocation of resources used in the reorganisation of the company; the affordability of crisis management; the encouragement of virtuous behaviour (avoiding moral hazard phenomena); the elimination of companies whose recovery is not possible (Ambrosini and Tron, 2016).

As stated in Principi, the main purpose of the recovery plan is to bring together the consensus of the stakeholders (among which the lenders in particular) towards the reorganisation of the company. The recovery plan must be able to convince the stakeholders to join the project by risking, contributing with financial and operational resources, or by accepting the sacrifices (renunciation of credits, acceptance of deferrals, 
partial loss of jobs, reconfiguration of the processes of procurement and sale, redefinition of the business model, etc.). The recovery plan is a guide for future actions, both for the management and for the stakeholders. It must allow all stakeholders to compare the expected outcomes with the results actually achieved, in order to grant any corrective actions and modifications to the recovery plan (Principi, paragraph 1.3.2).

\section{Characteristics of a turnaround project}

The planning for corporate restructuring, or turnaround, assumes the role of absolute pre-eminence in the management of business crises (O’Neill, 1986; Hoffman, 1989; Sudarsanam and Lai, 2001; Rasheed, 2005; Pearce and Robbins, 2008; Caputo and Tron, 2016).

According to Principi, once the causes of the business crisis have been diagnosed, the entrepreneur or managers must quickly define the guidelines for the recovery plan. The company's reorganisation plan must first of all illustrate the environment in which the company operates, the size of the company, the activity which is being carried out and its most typical and distinctive features (Principi, paragraph 5.2.1). This description is essential for crisis management and to obtain information on the level of the company dependence on the environment in which it operates.

The recovery plan must highlight the company salient facts from the recent past and the most remote ones, and the most relevant circumstances which led to the crisis. The survey must cover the technical, financial and human aspects, and must also be accompanied by an analysis of the performances particularly significant to understand the nature of the crisis in which the company is exposed (Caputo and Tron, 2016). Through the interpretation of the data, emerging from the aforementioned features, the managers and recipients of the recovery plan may draw preliminary conclusions regarding the causes of the crisis, first step for a crisis management (Müller, 1985; Pearson and Mitroff, 1993; Pearson and Clair, 1998; Pang et al., 2006; Booth, 2015). The survey must also highlight the past actions and remedies that have been implemented at the time of the crisis, assessing its effectiveness and timeliness. Once this examination has been completed, a conclusive part in which the various hypotheses based on the reconstruction actions that are expected to be implemented, including the execution time, the degree of feasibility and the presumable effects connected to them, must be formulated (Luzzana, 1986; Caputo and Tron, 2016).

The business plan, in line with Principi, must be drawn up taking into account the relaunch strategy that the managers intend to implement, the environmental conditions in which the company operates and the planned corporate restructuring operations, both internal and external. In fact, the recovery plan is a document that is aimed at both an internal and an external context (Principi, paragraph 1.3.3). This paper deals with the internal operations to be implemented for the resolution of the state of crisis.

Internal operations are all those activities designed to act on the company structure (e.g., staff reduction, rationalisation of management, etc.). Internal operations must produce effects on those areas that are considered inefficient, in order to guarantee a profitable future performance. As part of internal operations, the recovery plan must contain one or more alternatives to the main strategy. If the hypotheses on which the recovery plan is based do not occur, the plan must provide for alternative strategies. For 
each alternative strategy, advantages and disadvantages must be highlighted, as well as costs and returns, based on a scenario planning (Chermack, 2005; Postma and Liebl, 2005). An alternative reconstruction project corresponds to each alternative recovery strategy. Among the various alternative projects, it is necessary to prepare a pessimistic project, a worst case scenario (Bozza et al., 2001). It is necessary to predict the economic-financial consequences of each recovery strategy. Most companies have a system able to calculate and simulate the economic and financial consequences of programs over a medium/long-term time horizon, showing revenues, costs and other prospective information, in some cases even informally (Anthony et al., 1999).

The economic and financial forecasts are characterised by an unavoidable uncertainty (Graham and Carmichael, 2012; Samonas, 2015). This uncertainty increases when forecasts are made in crisis situations. For this reason, the recovery plan must not be formulated on the basis of objectives that are difficult to reach and with a low probability of success. In fact, recovery plans should be based on the best estimates of each relevant variable.

Every forecast is intrinsically characterised by its own degree of risk of fulfilment. It is therefore appropriate that the assumptions and hypothesis underlying the formulation of the recovery plan are subjected to sensitivity analysis (Bhat, 2008; Brigham and Ehrhardt, 2008). Sensitivity analyses are the quantitative representations of the uncertainties to which the recovery plan is subject to. In Principi it is said that the stress test represents a particular case of sensitivity analysis, in which the "uncertainty factor" connected to the hypotheses is mainly considered according to a pessimistic connotation. The objective of the stress test is therefore to analyse the effects on the main economic and financial data of the recovery plan as the negative change in one or more of the assumptions considered to be critical (jointly and/or separately). This analysis makes it possible to verify the sustainability of the recovery plan and the keeping of the covenants, also in the light of scenarios that are worse than the base scenario (Principi, paragraph 9.3).

Together with the strategic and operational turnaround it must be planned: a) an investment policy; a working capital policy; a net financial position and its composition compatible with the target of the recovery financial plan.

The financial package included in the forecast plan shall guarantee the industrial actions planned to allow the re-balancing of the financial situation during the time horizon of the recovery financial plan.

The action plan and its continuous monitoring during the entire duration of the turnaround project represents an essential element for a correct implementation of the recovery plan (Caputo and Tron, 2016; Ambrosini and Tron, 2016).

\section{Planning and execution of a recovery financial plan}

A positive outcome of a recovery plan requires a careful planning of all the necessary interventions to overcome the crisis and identify the timing of each intervention. The time component is a constraint frequently underestimated by shareholders, administrators and managers when the company is facing a crisis situation (Ambrosini and Tron, 2016). The temporal aspect can be considered a real strategic constraint with respect to which the sustainability of the possible recovery strategies can be verified. 
The macro-phases of the recovery plan can be outlined as follows:

- $\quad$ phase (1) strategy development;

- $\quad$ phase (2) negotiation with creditors of the restructuring proposal;

- $\quad$ phase (3) implementation of the recovery plan (action plan).

In the first phase, the anamnesis activities must be guided by the speed of execution, giving priority to the easiness rather than to the perfection of the solutions ("fast is better than perfect") (Danovi and Quagli, 2010). Yet, at this stage, it is very important to closely monitor cash flow, rather essential under certain circumstances in order to face the first phase of consolidation without the help of new financial resources.

In the early stages of the recovery process, the communication of the reconstruction project is an important success factor (Williams and Olaniran, 1998; Sweetser and Metzgar, 2007; González-Herrero and Smith, 2008, 2010; McDonald et al., 2010). At the early stages of the process, communication will be mainly internal, such as a shared tableau de bord, or dashboard. The tableau de bord is a set of ad hoc measures linked together through a series of cause-effect relationships. Each measure expresses a certain stage of the process, so that the indicators can provide an overall picture of the general systemic functioning. It was created to provide, at different organisational levels, supporting information to achieve company objectives. The tableau de bord is a tool used in the context of advanced management control systems, which starts from the recognition of financial results, up to a more in-depth analysis of the physical, technical and operational causes of the deviations related to the results of each business process. It should not only concern economic-financial indicators, but must also allow the analysis of the efficiency of the company management and of the operating processes, the level of customer satisfaction comparing financial data with indices about the quality provided and perceived by the customer (Epstein and Manzoni, 1997, 1998; Wegmann, 2000; Bourguignon et al., 2004). The two main objectives of the dashboard are represented by: a) the control of the performance of the key variables (the so-called Key Performance Indicators) and of the key processes; b) a brief and complete reading of the deviations of the company results for the definition of corrective actions.

This internal communication will be aimed at acquiring the information to understand the company situation under different and relevant profiles (product life cycle, strategic positioning, analysis of company costs, closing and forecast of financial statements, financial position, tension situations with stakeholders and/or with particular categories). Afterwards, the communication will also be external, since it is necessary to obtain consensus from the stakeholders, communicating them the overall project of recovery. The external communication phase is very delicate, since failure to succeed involves, very often in this phase, the questioning of business continuity and the possibility of insolvency situations (Giacosa and Mazzoleni, 2011, 2012).

Further strategic elements for the success of a recovery plan are represented by the identification of the governance principles and by the persons selected to manage the turnaround process. There can be several solutions in this sense. Some scholars have pointed out that, in Italian companies, often occur the following possibilities: there are managers who are specialised in the management of turnaround processes or, otherwise, there is the direct management of the restructuring process by the business owner himself (Danovi and Quagli, 2010). 
The following table summarises the strengths and weaknesses of the various turnaround process management solutions.

Table 1 The turnaround process. Comparison of management models

\begin{tabular}{|c|c|c|c|}
\hline \multicolumn{2}{|c|}{ Turnaround Manager } & \multicolumn{2}{|c|}{ Entrepreneur } \\
\hline Pro & Contra & Pro & Contra \\
\hline $\begin{array}{l}\text { Experience in } \\
\text { turnaround } \\
\text { processes }\end{array}$ & $\begin{array}{l}\text { Poor knowledge of the } \\
\text { company actuality }\end{array}$ & $\begin{array}{l}\text { Knowledge of the } \\
\text { business }\end{array}$ & $\begin{array}{l}\text { Not always objective } \\
\text { in the choices } \\
\text { regarding the reasons } \\
\text { that determined the } \\
\text { crisis }\end{array}$ \\
\hline $\begin{array}{l}\text { Discontinuity with } \\
\text { respect to the } \\
\text { previous } \\
\text { management }\end{array}$ & $\begin{array}{l}\text { More financial than } \\
\text { industrial approach }\end{array}$ & $\begin{array}{l}\text { Consolidated } \\
\text { relationships with } \\
\text { customers and suppliers } \\
\text { and in general with } \\
\text { stakeholders }\end{array}$ & $\begin{array}{l}\text { Continuity with } \\
\text { respect to the past }\end{array}$ \\
\hline $\begin{array}{l}\text { Carrier of new } \\
\text { skills and culture }\end{array}$ & $\begin{array}{l}\text { Possible carrier of } \\
\text { internal conflicts }\end{array}$ & $\begin{array}{l}\text { Strategic vision and } \\
\text { industrial approach }\end{array}$ & $\begin{array}{l}\text { Carrier of interests } \\
\text { potentially opposed to } \\
\text { those of creditors }\end{array}$ \\
\hline $\begin{array}{l}\text { Possibility of } \\
\text { making objective } \\
\text { choices }\end{array}$ & High cost & $\begin{array}{l}\text { Union between decision- } \\
\text { making power and } \\
\text { resources available for } \\
\text { the recovery plan }\end{array}$ & $\begin{array}{l}\text { Poor knowledge of } \\
\text { turnaround processes }\end{array}$ \\
\hline \multicolumn{2}{|c|}{ Paid on the base of goals } & $\begin{array}{l}\text { Motivation to implement } \\
\text { the recovery plan to } \\
\text { protect economic and } \\
\text { image interests }\end{array}$ & $\begin{array}{l}\text { Centric decision- } \\
\text { making and decisions } \\
\text { based on emotionality }\end{array}$ \\
\hline
\end{tabular}

Source: Danovi and Quagli (2010)

It must be pointed out that a delicate aspect of the recovery financial plans is represented by their feasibility. According to Principi, recovery plans are achievable when they meet the following conditions (Principi, Chapter 5):

- they must be compatible with the characteristics and trends of the external environment (e.g. any growth in revenues must be consistent with the expected growth rates of the sector and with the competitive positioning of the company);

- they must be internally coherent, both from the point of view of the correlations among variables and the availability of resources (e.g. productivity improvements that are realistic and consistent with the technical returns of fixed assets and with the work rhythms of the staff);

- they must have a medium-normal degree of difficulty in their implementation, such that their realisation can be considered probable and, in any case, that their valuation is the best estimate of future events;

- they must be supported by concrete elements that demonstrate, even in the short term, an evolution consistent with the recovery plan (e.g. a binding commitment by a third-party lender if the recovery plan is based on the acquisition of new financial resources), and, in any case, the plan must lead to the resolution of the crisis over a maximum time horizon of 3-4 years. 


\section{Company organisation: a strategic resource in the recovery process}

Organisational change is an important aspect related to recovery planning and turnaround process (Kanter, 1992; Armenakis and Fredenberger, 1997; Barker and Duhaime, 1997; Pearson and Clair, 1998; Carroll and Hatakenaka, 2001; Wang, 2008). After drawing up the recovery planning, the manager must establish which organisational structure is able to support and facilitate its implementation. The planned organisational structure must be able to ensure that the recovery plan is implemented in the most efficient and effective possible way, while at the same time recovering sustainable long-term competitive advantages that will allow the crisis to be overcome.

Since the organisational change may involve the insertion of new resources (human, material, financial, etc.), this should be highlighted in the recovery plan (Principi, paragraph 6.3.3). In particular, it is necessary to emphasise the consistency between the company resources that are expected to be introduced and the interventions that the reorganisation plan requires (Principi, paragraph 6.3.4).

Since the recovery plan implies the pursuit of a specific strategy, it is necessary to prepare an organisational structure to support the implementation of the strategy. The literature has largely focused on the strong links between strategies and structures (Chandler, 1962; Sloan, 1964; Cafferata, 2009; Paletta et al., 2016).

When designing a new organisational structure consistent with the strategies defined in the recovery plan, some questions must be inquired. These questions are useful to assess the operational feasibility of the recovery plan (Ambrosini et al., 2013):

- who will implement the recovery plan?

- with which professional skills and ability will this subject/team implement the recovery plan?

- what activities should be carried out to implement the recovery plan?

- which activities are crucial for the success of the crisis recovery?

The recovery plan, at least in the managers" intentions, is always "feasible" and suitable to restore the conditions of economic and financial equilibrium. As a matter of fact, however, many plans disregard expectations, even if the construction of the economicfinancial performance indicators is based on the design of reasonable assumptions. One of the main causes of negative performances is that the recovery plan is not articulated with an adequate level of detail (Reina, 2003). Often, strategic, financial and organisational information does not reach sufficient levels of detail. Organisational information is often lacking, and this leads to negative performance in the implementation of recovery plans. It is not possible, in fact, to support the implementation of the actions foreseen in the recovery plan if it does not identify the operating procedures that allow, through a renewed organisational structure, to achieve the sequence of planned activities (Ambrosini and Tron, 2016).

The organisational element is therefore usually underestimated. Even if some industrial plans are complete, with regard to the planning of the new organisational structure, the phases of the organisational restructuring are often not synchronised with respect to the operational activities envisaged in the action plan. It should however be stressed that redesigning the organisational structure, especially in a recovery area, is a very complex activity that requires specific skills and a particular attention both at the 
level of the "macro" organisational structure (roles, responsibilities, skills, processes, procedures, etc.) and on a "micro" cultural level (attitudes, behaviours, etc.).

The organisational redesign must focus on the main success factors that are, in turn, the basis of change management activities (Todnem, 2005; Graetz et al., 2006; Diefenbach, 2007). If the organisational changes determine significant interventions on the staffs and the number of employees, it is necessary to include information on the main business sectors and organisational units involved in the recovery plan. When the recovery plan involves reducing the workforce, the cost/benefit estimate must be provided. If, on the other hand, the recovery plan highlights the need to maintain and manage staff redundancies, it is necessary to face extraordinary costs and the relative timing (Principi, paragraph 6.3.4).

Interventions affecting the organisational structure must therefore be consistent with the industrial and financial strategy to ensure maximum support for the specific business actions envisaged in the recovery plan. The sequence of the various organisational interventions must also be synchronised to the business actions, according to the rules of prerequisites. The objective of the planned organisational structure will be to guarantee the sustainability over time of the performance forecast by the recovery plan, both in the short and in the long term.

\section{Organisational recovery as an element of the action plan}

The process of organisational recovery must follow three phases (Ambrosini and Tron, 2016):

1 the "assessment" phase;

2 the "design" phase;

3 the "implementation" phase.

The three phases must be managed by a multi-functional team, in order to adequately take into account all the sectors of the company involved in the redesign of the organisational structure. The team must be able to consider the results-objectives to be achieved at the business level, and on their basis to redesign the organisational structure.

In other words, organisational changes must be planned and have to be consistent with the changes envisaged for the business model of the company.

The process of organisational redesign must be managed by a Chief Restructuring Officer (CRO), i.e. a manager/professional who is responsible for the process of operational and financial restructuring of the company in crisis (Waisman and Lucas, 2008). The CRO embodies functions which range from liquidity management, to the implementation of the restructuring plan, to the selection and training of managerial figures that can strengthen the team. The team managed by the CRO must be set up and communicated in a formal manner to the entire company. The CRO takes on himself the responsibility of the management and implementation of the company's operational, financial and organisational recovery process. The delegation of powers to the CRO, throughout the recovery phase, must be clear and well known within the company, and his hierarchical position must be of on of high standing. In particularly delicate and complex cases, this figure coincides with the role of General Manager or Chief Executive Officer of the company in crisis. The $\mathrm{CRO}$ represents the change agent, i.e. the catalyst 
element of the set of processes subjected to complex and dynamic changes (Ford and Ford, 1995; Armenakis and Bedeian, 1999; Westover, 2010).

The key elements of a performing organisational model are apparently conceptual but in reality they have strong characteristics of concreteness and measurability. Concreteness and measurability are necessary since it is necessary to verify, as we proceed with the recovery, any possible deviations between planned objectives and actually achieved results. The analysis of the deviations is necessary to prepare adequate corrective actions during the implementation of the recovery project (Ambrosini and Tron, 2016).

There are some "macro" elements on the basis of which the organisational structure of the company must be redesigned. These elements are:

- management based on principles;

- leadership;

- involvement and authority;

- open communication;

- focus on business results;

- focus on the customer/consumer;

- regulation of organisational changes;

- learning-oriented environment;

- development of opportunities;

- transversal learning.

The organisational infrastructure must also be designed on the basis of "micro" elements in order to accurately and punctually calibrate the business interventions envisaged in the reorganisation plan. It is necessary, therefore, to compare the current business situation with the organisational structure that generated it (analysis phase), and then to identify all the strategic organisational steps necessary to achieve the expected business situation (design phase). The analysis phase (assessment) is perhaps the most critical because the causes of the crisis must be sought by evaluating systematically the different profiles of company management and identifying how much the crisis derives from an inadequate organisational structure. It will be necessary to conduct this diagnosis correctly as the assessment has to be is as effective as possible and, above all, it has to be oriented towards the actionability of the recovery and business plan (Slatter and Lovett, 1999).

Once the assessment phase has been carried out, it will be necessary to proceed with the actual interventions aimed at the organisational change, which will have to follow the following steps (Ambrosini and Tron, 2016):

- $\quad$ to trace the causes that led to current results;

- to identify the problems/opportunities of the organisational design;

- to identify the operational strategy to carry out organisational change;

- to evaluate the operational strategy of organisational change. 
Organisational change must be accompanied by a real cultural change (Bate, 1994; Schneider et al., 1996; Rashid et al., 2004; Alvesson and Sveningsson, 2016). In fact, cultural change is able to facilitate the implementation of the interventions envisaged in the recovery plan. In other words, cultural change must be functional to the realisation of all the activities forecast in the recovery process, which are fundamental for the expected performance (Tocquigny and Butcher, 2012). It is therefore necessary to provide:

- sensitivity \& stress analysis: it provides simulations on the feasibility of the recovery plan based on the possible variability of the basic assumptions and, consequently, of the company performance;

- the deployment plan and the action plan focused on "organisational leadership", which must be based on the careful matching between the "manager" and the "plan actions", where the commitment allows a more controlled transition in the switch from strategy to concrete actions (Morgan et al., 2008).

- the monitoring plan, which provides for the preparation of the "KPI scorecard" (Key Performance Indicators), which allows the monitoring activities to be planned after the preparation of the recovery plan. The KPI scorecard allows to schedule the "business reviews", during which the deviations are analysed and appropriate plans are formulated for the recovery of the eventual lost efficiency (contingency).

During each project phase, from the formulation to the implementation of the recovery plan, there must always be a reference to the relative operational KPI for each economicfinancial KPI (with related organisational impacts). This identification will also facilitate the deployment and monitoring phases, allowing a simpler and direct allocation of resources in the restructured company organisation. KPIs can be both economic-financial and asset-type, as well as qualitative and quantitative indicators of different nature (Kaplan and Norton, 2001; Franceschini et al., 2007; Parmenter, 2015).

Figure 1 Individuation of KPIs

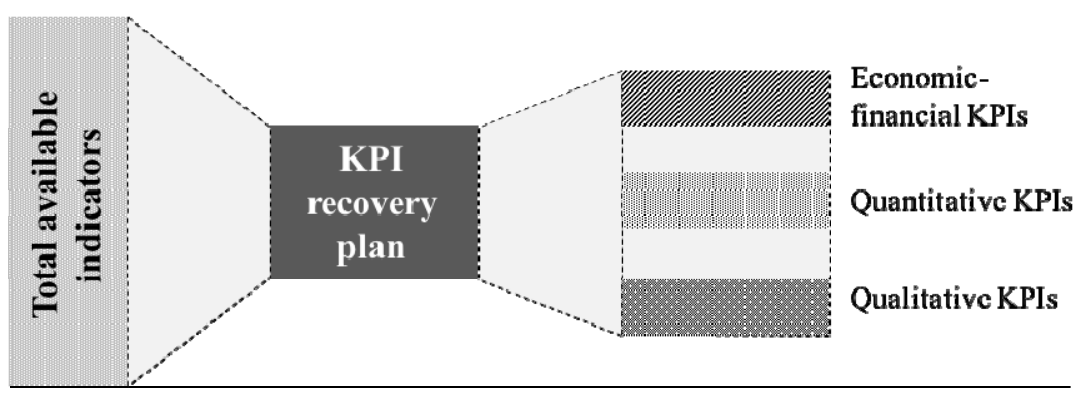

The whole process is characterised by a precise correlation of underlying fundamental operating variables and derived performance variables.

The correct execution of these phases determines the probability of success of the recovery plan, and the consequent achievement of the expected performance deriving from the execution of the plan itself.

The analysis of the deviations (so-called delta-performance), that should be carried out during the execution phase, between the performance envisaged in the recovery plan and the finalised one (monitoring), represents important occasion for evaluation and 
improvement (fine tuning) of the operating parameters that govern the performance. In this way it is possible to develop the skills for the identification of the "basic" causes (of the underperformance) and of the relative contingency actions (and back up) to be performed.

\section{Feasibility of the recovery financial plan as a result of a correct execution process (deployment)}

In order to minimise the risk of a possible inadequate implementation of the reorganisation plan, the Principi provide for a specific deployment and monitoring phase to be described, together with the preparation of specific contingency plans in order to mitigate any unexpected unsatisfactory under-performance, which, in some cases, could undermine the success of the recovery operation (Paton and McCalman, 2008; Anderson and Anderson, 2010).

The feasibility of the recovery plan is the high probability that its correct implementation will record the expected performance.

Feasibility, therefore, is strictly related to an organisational redesign that is coherent, not only with a renewed strategic architecture, but also, and above all, with all the individual elements constituting the specific organisational structure (Child, 2005; Burton et al., 2006; Burton et al., 2011):

- skills;

- work;

- the organisational structure;

- decision-making and authority delegations;

- information and reporting system;

- performance-based remuneration system.

The organisational change required to successfully implement the reorganisation plan must therefore be well described within the recovery plan itself with an appropriate level of detail, representing the areas of specific assumptions of accountability of the actions defined to govern and manage the company (Reina, 2003; Lenahan, 2011).

Such detailed organisational analysis immediately allows the identification of the possible gap between the current situation that led to the crisis and the future situation envisaged in the recovery plan.

The approaches to cover this gap (technical training, management training, transfers and/or merging of functions, redefinition of responsibility and command strategies, etc.) must be included in the recovery plan and must, above all, be planned, on the basis of priorities and prerequisites, so that the new organisation is adequate to support the effective and efficient implementation of actions to support the recovery plan (Lewis, 2006; Slatter and Lovette, 1999; Butera, 2009; Trequattrini, 2004; Bianchi Martini, 2009; Foglio, 2011; Paletta et al., 2016).

Equally, therefore, to the economic gap analysis (which normally is articulated through the Key Performance Indicators of economic, financial and equity nature), it is necessary to structure the organisational gap analysis. In short, the Action Plan, which 
expresses the ways in which the expected performance level will be achieved, is nothing but a system of representation of "Delta-KPI" (Principi, paragraph 8.8).

The Key Performance Indicators (KPI) subject to deployment and monitoring are usually the traditional parameters of economic, financial and equity nature (revenues, EBITDA, Cash Flow From Operations, Net Assets, Net Financial Position, etc.).

Based on the results of the sensitivity \& stress analysis, it is also advisable to monitor the fundamental elements of the Circulating Capital (above all the inventory rotation and the collection times of the customers - DSO: Days of Sales Outstanding). In some cases, the KPIs have also a qualitative nature and are related to events well identified in the recovery plan, for example actions regarding organisational aspects (manager change, training, delegations of responsibility, etc.).

A Delta-Performance scheme of operational value, well-structured and segmented at the highest possible level of detail, can be used as an effective tool for the allocation of resources, thus ensuring the right focus, abilities and skills required for the inherent complexity level of the recovery plan.

In this regard, the sensitivity analysis of the "base" recovery plan will make it possible to predict, in addition to "breaking" scenarios of the recovery plan, also the "delta-performance" scenarios that will have to be subjected to a deployment control (Akao, 2004; Hino, 2006) and to a careful monitoring by the company management in order to guarantee the achievement of the objectives set out in the plan.

A graphical representation of the Delta-Performance scenarios analysis is shown in Figure 2.

Figure 2 Sensitivity analysis e and determination of "delta performance" scenarios (Caputo and Tron, 2016)

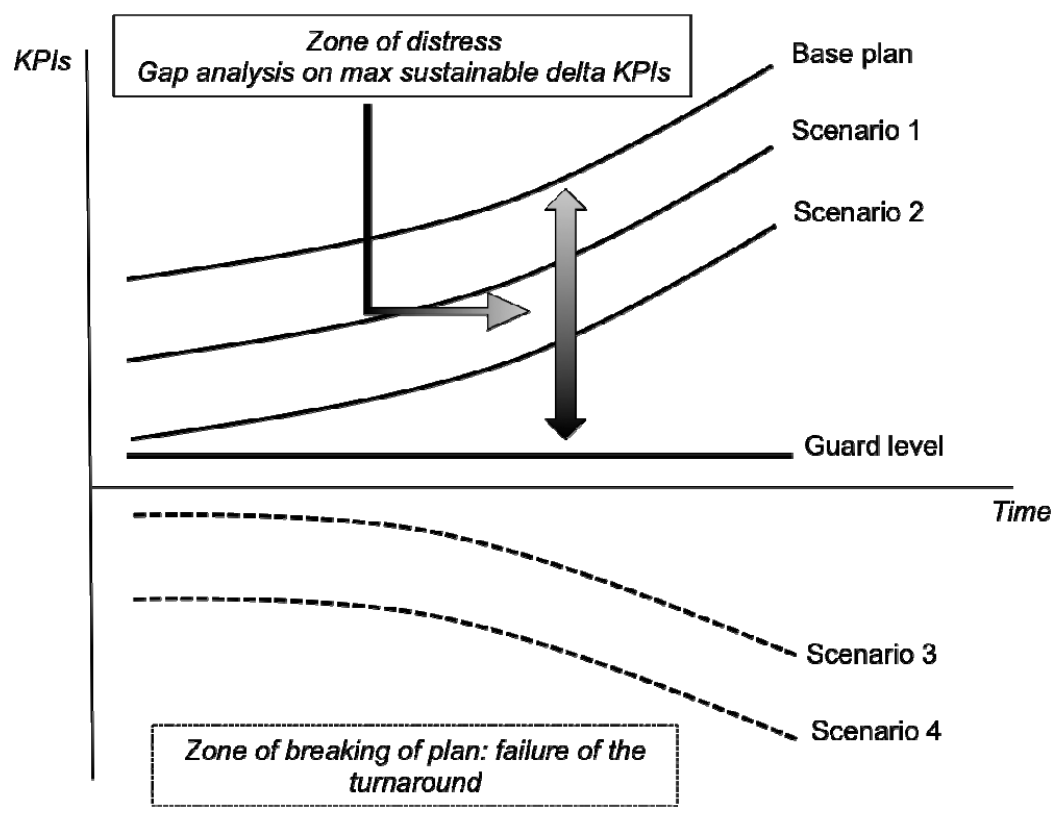

The figure described above identify both the line of the "Guard level" that the "default line". Both must be constantly monitored and need appropriate deployment. 
The Deployment consists of three critical moments (Ambrosini and Tron, 2016):

1 sharing with the entire company and the stakeholders the contents of the recovery plan;

2 assigning responsibilities in the action plans;

3 starting the preparation of critical KPI scorecards.

The assignment of responsibilities will start in concomitance with the launch of those operational changes needed to adequately support the taking charge of the plans by the appointed managers (training, reporting, organisational restructuring, etc.).

The time intervals characterising the start of a recovery plan are obviously limited and it will be highly unlikely to be able to plan all the actions with an appropriate chronological sequence. Therefore, during the start-up phase, the Deployment will have to serve an imperfect organisational structure which, in parallel, will be the object of a continuous re-engineering. This aspect, however, will not necessarily be a serious problem for the company management, if, during the drafting of the recovery plan, the Delta-Organisation has already been identified, analysed, redesigned and described with all the temporal references to build, as quickly as possible, the right business operating structure (Caputo and Tron, 2016).

The production of the scorecards related to critical KPIs, to be included in the recovery plan, is an equally important activity that, if well designed from the beginning and appropriately described in the plan, allows a broad measurability of the current and expected performance. In this way, it is possible to take note of the presence of a "control dashboard" that will allow the company management to have the opportunity to periodically check the correct achievement of the actions envisaged in the recovery plan (Kaplan and Norton, 1996; Lewis, 2006; Cerica, 2010).

The most important elements of the scorecard are two:

1 the correct definition of targets;

2 the correct definition of the measurement/reading frequency.

As far as the choice of targets is concerned, not only the values associated with the "base" plan but also those related to the safety thresholds identified in the sensitivity analyses should be taken into account. In particular, the adoption of two threshold values is recommended: the first one identifies the level of "guard" beyond which the business is at risk; the second one identifies the real level of "break/default". The area between the guard value and the break/default value, i.e. the high stress zone, must be designed in line with the organisation's capacity and speed of reaction. In other words, the Delta-KPI, in order to be restored in the range of the correct values, will require the execution of specific actions (so-called "contingency") that the organisation will realise with a certain delay compared to the Delta-KPI, and this delay must not be higher than the "drift" time of the KPI towards the breaking/default threshold.

\section{The monitoring of the recovery financial plan}

The monitoring process must already be scheduled during the formulation of the recovery plan hypotheses. The same hypotheses on which the planned interventions are 
based must be the object of the monitoring activity, during the implementation phase of the recovery plan (Caputo and Tron, 2016). The hypotheses (or "fundamental indicators"), once they have been formulated, during the planning phase, are always associated with the responsible managers, who are then appointed as accountable for those areas related to the hypotheses in question. Certainly, in every company dashboard (KPI Scorecard), the deviations of the economic-financial-equity indicators that represent the state of health of the company must be reported. However, the monitoring will allow a real "basic root-cause analysis" that will give more clarity on the reasons underlying the deviation of the performance values (Fiscal-Year-To-Date) from the values forecasted in the recovery plan.

The basic steps for a reliable and effective monitoring process are the following (Ambrosini and Tron, 2016):

- defining, during the formulation of the recovery plan, the assumptions of the recovery plan and the relational algorithms for the correlation between these assumptions and the economic-financial-equity performance in a clear and precise manner;

- formulating the sensitivity analysis on the recovery plan's assumptions and define the maximum variability that maintains the performance in the perimeter of business continuity. This variability/perimeter will then be used as a landmark, in the monitoring process, to increase the sensitivity in the management for the implementation of any corrective actions to avoid the entrance into the default perimeter;

- defining, during the formulation of the recovery plan, the accurate association between hypotheses; organisational managers, during the implementation of the recovery plan, will work to verify the variability of the performance as a consequence of the variability of the hypotheses;

- translating both the hypotheses and the performance indicators into operational terms for an efficient and concrete possibility of daily performance management. For example: instead of allocating a target of $\mathrm{X} \mathrm{M} €$ for stock/warehouse to the warehouse manager as part of a net working capital reduction action, the $\mathrm{X}$ M€ value is translated into the number of SKUs (Statistical Keeping Units, i.e. the number of references managed in the company), in number of rotation days or in a particular activation of consignment goods policy to be agreed with suppliers.

- institutionalising the accountability matrix, that is the association between the operational indicators (hypotheses) underlying the performance and organisational responsible, and the correlation of the sharing of the recovery plan leadership to the organisational levels to which this associative matrix refers to.

- institutionalise the monitoring process (gap analysis), keeping punctually and strictly the managers' focus on the effects of the deviations of the operating indicators towards the deviations of the company's performance.

The heart of the process for an effective Monitoring is represented by the institutionalisation of a cycle of periodic business reviews that must be incorporated into the previously illustrated operational \& corporate governance process. These periodic business reviews will have a defined agenda focused on the identification of the 
deviations of the operating parameters (underlying and related to the economic-financial performance) with respect to their objective value of the recovery plan for the fiscalyear-to-date reference period.

Figure 3 Monitoring framework

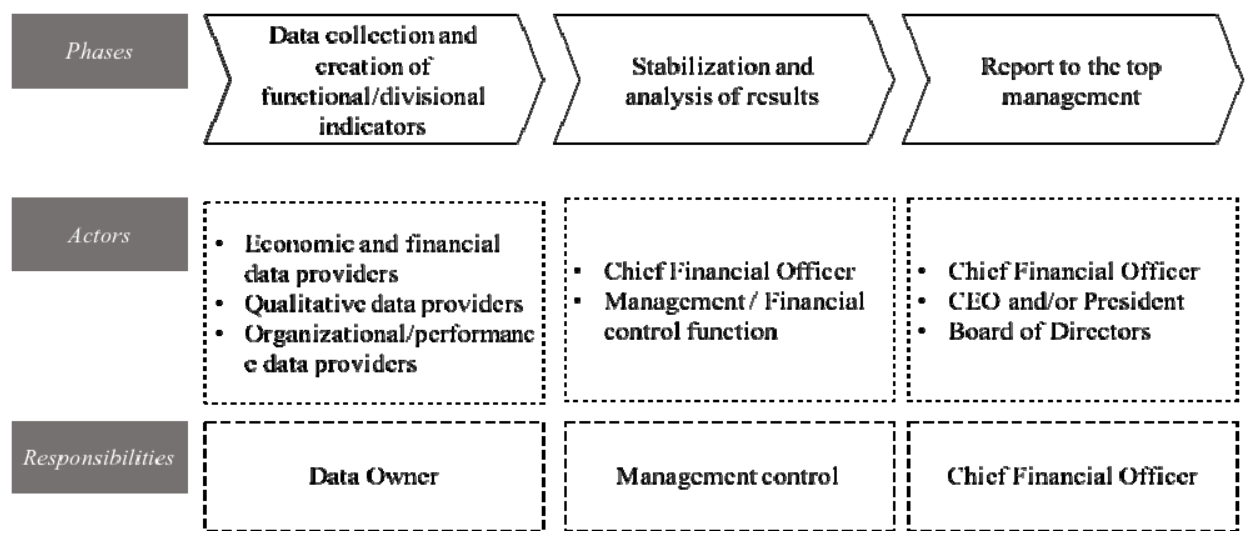

In order to facilitate the process of assigning responsibilities to the actions of the reorganisation and "contingency" plan in the event of significant deviations, it is recommended to use a table summarising the processes of "Deployment" and "Monitoring" through the KPI Scorecard, which represents the performance monitoring tool available to the company leadership and an analysis of the different performance scenarios of the recovery plan.

Once the reorganisation plan, in its basic assumptions and in the sensitivity analysis simulations, has expressed, with clarity and detail, all the actions that the company will have to pursue in order to achieve the objectives underlying the expected economic, financial and patrimonial performance, it is necessary to start the Monitoring phase.

Monitoring is a "never-ending process" that every company must have institutionalised to evaluate, with a certain frequency, the health status of the business (Akao, 2004; Lewis, 2006; Hino, 2006; Zanoni and Campedelli, 2007; Zanoni, 2009).

Principi are very clear on this point, stating that the monitoring activity will be facilitated if the recovery plan provides intermediate reference targets in relation to which the implementation of the recovery plan must be verified (milestones) (paragraph 9.1.6).

Monitoring is one of the most important processes of operational governance during the implementation of a recovery plan because the measurement of the current performance status towards the expected one is a mandatory condition to assess the execution of countermeasures in case of negative deviations.

Therefore, it is necessary to predispose a calendar (business review plan) in which the KPIs in question can be measured with a frequency aligned not only with the natural timing of occurrence (e.g.: number of orders, invoicing, delayed collection, payments, etc.), but also with the time of organisational reaction to prepare a contingency plan.

It is important to underline that in case of significant deviations it will be necessary to proceed with the drafting of a new recovery plan. Changes to the recovery plan can be considered substantial when: 
- there is a discrepancy with respect to the contents and the provisions of the recovery plan, such as to affect the feasibility of the same and not allow compliance with the timing and methods of the process to overcome the crisis;

- the deviation cannot be absorbed by corrective actions and adjustment mechanisms, as they are not foreseen and/or not sufficient.

It should also be emphasised that a good monitoring process is not only a "mechanical occurrence" linked to the production of reporting (scorecard) and the analysis of deviations (gap analysis), but it is above all a cultural element because it implies, in the management of operational responsibilities, the accountability, which represents a real organisational engine, an expression of fundamental leadership for every successful company.

\section{Conclusion}

The present article has presented an investigation of the Italian system for managing corporate crises: in particular, the key aspects of the process of recovery planning have been analysed. The presence of a planned monitoring of the KPI's of Delta-Performance represents a distinctive element of a recovery plan's quality in which, since its creation, the critical elements have to be kept under control at intervals with different periodicities, in order to achieve the objective of restoring the economic, patrimonial and financial equilibrium of the company in crisis.

\section{References}

Acquier, A., Gand, S. and Szpirglas, M. (2008) 'From stakeholder to stakeholder's management in crisis episodes: a case study in a public transportation company', Journal of Contingencies and Crisis Management, Vol. 16, No. 2, pp.101-114.

Akao, Y. (2004) Hoshin Kanri: Policy Deployment for Successful TQM, Productivity Press, New York.

Alesi, P. (2008) 'Building enterprise-wide resilience by integrating business continuity capability into day-to-day business culture and technology', Journal of Business Continuity \& Emergency Planning, Vol. 2, No. 3, pp.214-220.

Alvesson, M. and Sveningsson, S. (2016) Changing Organizational Culture: Cultural Change Work in Progress, Routledge, New York.

Ambrosini, S. and Tron, A. (Eds.) (2016) Piani di ristrutturazione dei debiti e ruolo dell'attestatore. "Principi di attestazione" e riforma del 2015, Zanichelli, Bologna.

Ambrosini, S., Andreani, G. and Tron, A. (2013) Crisi d'impresa e restructuring. Aspetti economico-aziendali, giuridici e fiscali alla luce delle prime applicazioni e interpretazioni delle norme introdotte dalla legge 134/2012, Il Sole 24 Ore, Milan.

Anderson, D. and Anderson, L.A. (2010) Beyond Change Management: How to Achieve Breakthrough Results Through Conscious Change Leadership, Pfeiffer, San Francisco, CA.

Anthony, R.N., Hawkins, D.F. and Merchant, K.A. (1999) Accounting. Texts and Cases, Irwin/McGraw-Hill, Boston.

Armenakis, A.A. and Bedeian, A.G. (1999) 'Organizational change: a review of theory and research in the 1990s', Journal of Management, Vol. 25, No. 3, pp.293-315. 
Armenakis, A.A. and Fredenberger, W.B. (1997) 'Organizational change readiness practices of business turnaround change agents', Knowledge and Process Management, Vol. 4, No. 3, pp.143-152.

Barker, V.L. and Duhaime, I.M. (1997) 'Strategic change in the turnaround process: theory and empirical evidence', Strategic Management Journal, Vol. 18, No. 1, pp.13-38.

Bate, S.P. (1994) Strategies for Cultural Change, Butterworth-Heinemann, Oxford.

Bhat, S. (2008) Financial Management: Principles and Practice, Excel Books, New Delhi.

Bianchi Martini, S. (2009) Introduzione all'analisi strategica dell'azienda, Giappichelli, Turin.

Bolton, P. and Scharfstein, D.S. (1996) 'Optimal debt structure and the number of creditors', Journal of Political Economy, Vol. 104, No. 1, pp.1-25.

Booth, S.A. (2015) Crisis Management Strategy. Competition and Change in Modern Enterprises, Routledge, New York.

Botha, J. and Von Solms, R. (2004) 'A cyclic approach to business continuity planning', Information Management \& Computer Security, Vol. 12, No. 4, pp.328-337.

Botosan, C.A. and Plumlee, M.A. (2002) 'A re-examination of disclosure level and the expected cost of equity capital', Journal of Accounting Research, Vol. 40, No. 1, pp.21-40.

Bourguignon, A., Malleret, V. and Nørreklit, H. (2004) 'The American balanced scorecard versus the French tableau de bord: the ideological dimension', Management Accounting Research, Vol. 15, No. 2, pp.107-134.

Bozza, E., Bozza, L., Bozza, M., Lucido, N. and Marcello, R. (2001) La crisi di impresa, Edizioni Giuridiche Simone, Napoli.

Brigham, E. and Ehrhardt, M. (2008) Financial Management: Theory \& Practice, Thomson, Mason, USA.

Burton, R.M., Eriksen, B., Håkonsson, D.D. and Snow, C.C. (Eds) (2006) Organization Design: The Evolving State-of-the-Art, Springer Science + Business Media, New York, NY.

Burton, R.M., Obel, B. and DeSanctis, G. (2011) Organizational Design: A Step-by-Step Approach, Cambridge University Press, New York.

Butera, F. (2009) Il cambiamento organizzativo. Analisi e progettazione, Laterza, Bari.

Cafferata, R. (2009) Management in Adattamento. Tra Razionalità Economica e Imperfezione dei Sistemi, Il Mulino, Bologna.

Caputo, A. and Tron, A. (2016) 'The attestation of corporate turnaround plans in Italy: operating problems and possible solutions', International Journal of Critical Accounting, Vol. 8, No. 1, pp.30-44.

Carroll, J.S. and Hatakenaka, S. (2001) 'Driving organizational change in the midst of crisis', MIT Sloan Management Review, Vol. 42, No. 3, pp.70-79.

Cerica, R. (2010) Cultura organizzativa e performance economico-finanziarie, Firenze University Press, Florence.

Cerullo, V. and Cerullo, M.J. (2004) 'Business continuity planning: a comprehensive approach', Information Systems Management, Vol. 21, No. 3, pp.70-78.

Chandler, A.D. (1962) Strategy and Structure. Chapters in the History of the American Industrial Enterprise, MIT Press, Massachusetts Institute of Technology.

Chermack, T.J. (2005) 'Studying scenario planning: theory, research suggestions, and hypotheses', Technological Forecasting and Social Change, Vol. 72, No. 1, pp.59-73.

Child, J. (2005) Organization: Contemporary Principles and Practice, John Wiley \& Sons, Chichester, West Sussex.

Dallocchio, M. and Salvi, A. (2004) Finanza d'azienda, Egea, Milan.

Danovi, A. and Quagli, A. (Eds) (2010) Crisi aziendali e processi di risanamento, Ipsoa, Milan.

Diefenbach, T. (2007) 'The managerialistic ideology of organisational change management', Journal of Organizational Change Management, Vol. 20, No. 1, pp.126-144. 
Donaldson, G. (2000) Corporate Debt Capacity: A Study of Corporate Debt Policy and the Determination of Corporate Debt Capacity, Beard Books, Washington, D.C.

Doughty, K. (Eds) (2001) Business Continuity Planning: Protecting Your Organization's Life, CRC Press LLC, Boca Raton, Florida.

Dubrovski, D. (2004) 'Peculiarities of managing a company in crisis', Total Quality Management \& Business Excellence, Vol. 15, Nos. 9-10, pp.1199-1207.

Epstein, M. and Manzoni, J.F. (1997) 'The balanced scorecard and tableau de bord: translating strategy into action', Management Accounting, Vol. 79, No. 2, pp.28-36.

Epstein, M. and Manzoni, J.F. (1998) 'Implementing corporate strategy: from tableaux de Bord to balanced scorecards', European Management Journal, Vol. 16, No. 2, pp.190-203.

Foglio, A. (2011) Change management come strategia d'impresa. Governare futuro e cambiamenti e tramutarli in opportunità, Franco Angeli, Milan.

Ford, J.D. and Ford, L.W. (1995) 'The role of conversations in producing intentional change in organizations', The Academy of Management Review, Vol. 20, No. 3, pp.541-570.

Franceschini, F., Galetto, M. and Maisano D. (2007) Management by Measurement: Designing Key Indicators and Performance Measurement Systems, Springer, Berlin.

Galeotti, M. (2008) La finanza nel governo dell'azienda, Apogeo, Milan.

Galeotti, M. and Garzella, S. (Eds) (2013) Governo strategico dell'azienda, Giappichelli, Turin.

Giacosa, E. and Mazzoleni, A. (2011) 'Survival and recovery planning of crisis in firm: the recent Italian experience', Estonian Business Review (EKK TOIMETISED), Vol. 28, pp.7-21.

Giacosa, E. and Mazzoleni, A. (2012) Il progetto di risanamento dell'impresa in crisi, Giappichelli, Turin.

Goh, M.H. (1996) 'Developing a suitable business continuity planning methodology', Information Management \& Computer Security, Vol. 4, No. 2, pp.11-13.

González-Herrero, A. and Smith S. (2008) 'Crisis communications management on the web: how internet-based technologies are changing the way public relations professionals handle business crises', Journal of Contingencies and Crisis Management, Vol. 16, No. 3, pp.143153.

González-Herrero, A. and Smith, S. (2010) 'Crisis communications management 2.0: organizational principles to manage crisis in an online world', Organization Development Journal, Vol. 28, No. 1, pp.97-105.

Goode, R.M. (2011) Principles of Corporate Insolvency Law, Sweet \& Maxwell, London.

Graetz, F., Rimmer, M., Lawrence, A. and Smith, A. (2006) Managing Organisational Change, John Wiley \& Sons, Malden, Massachusetts.

Graham, L. and Carmichael, D.R. (2012) Accountants' Handbook: Financial Accounting and General Topics, John Wiley \& Sons, Hoboken, New Jersey.

Guatri, L. (1995) Turnaround. Declino, crisi e ritorno al valore, Egea, Milan.

Hino, S. (2006) Inside the Mind of Toyota: Management Principles for Enduring Growth, Productivity Press, New York.

Hoffman, R.C. (1989) 'Strategies for corporate turnarounds: what do we know about them?' Journal of General Management, Vol. 14, No. 3, pp.46-66.

Johnson, S. (1997) 'An empirical analysis of the determinants of corporate debt ownership structure', Journal of Financial and Quantitative Analysis, Vol. 32, No. 1, pp.47-69.

Kanter, R.M., Stein, B.A. and Jick, T.D. (1992) The Challenge of Organizational Change, The Free Press, New York.

Kaplan, R.S. and Norton, D.P. (1996) The Balanced Scorecard: Translating Strategy Into Action, Harvard Business School Press, Boston, Massachusetts.

Kaplan, R.S. and Norton, D.P. (2001) 'Transforming the balanced scorecard from performance measurement to strategic management: part I', Accounting Horizons, Vol. 15, No. 1, pp.87104. 
Kash, T.J. and Darling, J.R. (1998) 'Crisis management: prevention, diagnosis and intervention', Leadership \& Organization Development Journal, Vol. 19, No. 4, pp.179-186.

Leland, H.E. (1994) 'Corporate debt value, bond covenants, and optimal capital structure', The Journal of Finance, Vol. 49, No. 4, pp.1213-1252.

Lemmon, M.L., Roberts, M.R. and Zender, J.F. (2008) 'Back to the beginning: persistence and the cross-section of corporate capital structure', The Journal of Finance, Vol. 63, No. 4, pp.15751608.

Lenahan, T. (2011) Turnaround, Shut-down and Outage Management: Effective Planning and Step-by-Step Execution of Planned Maintenance Operations, Butterworth-Heinemann, Oxford.

Lewis, G. (2006) Organizational Crisis Management: The Human Factor, Taylor \& Francis, Boca Raton, Florida.

Lindström, J., Samuelsson, S. and Hägerfors, A. (2010) 'Business continuity planning methodology', Disaster Prevention and Management: An International Journal, Vol. 19, No. 2, pp.243-255.

Luzzana, R. (1986) 'Alcuni aspetti di rilievo nella formulazione del piano di risanamento', in Cattaneo, M. et al. (Eds): Crisi d'impresa ed amministrazione controllata, Giuffrè, Milan, pp.213-214.

Marra, F.J. (1998) 'Crisis communication plans: poor predictors of excellent crisis public relations', Public Relations Review, Vol. 24, No. 4, pp.461-474.

McDonald, L.M., Sparks, B. and Glendon, A.I. (2010) 'Stakeholder reactions to company crisis communication and causes', Public Relations Review, Vol. 36, No. 3, pp.263-271.

Milman, D. (1991) 'Priority rights on corporate insolvency', in Clarke, A. (Eds): Current issues in insolvency law. Current legal problems, Stevens, London, pp.57-85.

Morgan, M., Levitt, J. and Malek, W. (2008) Executing your strategy - How to Break It Down and Get It Done, Harvard Business School Press, Boston, Massachusetts.

Morin, R. and Jarrell, S. (2000) Driving Shareholder Value. Value-building Techniques for Creating Shareholder Wealth, McGraw-Hill, New York.

Müller, R. (1985) 'Corporate crisis management', Long Range Planning, Vol. 18, No. 5, pp.38-48.

O’Neill, H.M. (1986) 'Turnaround and recovery: What strategy do you need?', Long Range Planning, Vol. 19, No. 1, pp.80-88.

Osadchy, E.A. and Akhmetshin, E.M. (2015) 'Development of the financial control system in the company in crisis', Mediterranean Journal of Social Sciences, Vol. 6, No. 5, pp.390-398.

Ozkan, A. (2000) 'An empirical analysis of corporate debt maturity structure', European Financial Management, Vol. 6, No. 2, pp.197-212.

Paletta, A., Alimehmeti, G. and Tron A. (2016) 'Business administrative systems and bakruptcy financial distress', Il Governo aziendale tra tradizione e innovazione, 2016, pp.VI_73-VI_90, FrancoAngeli Editore, Milan.

Pang, A., Cropp, F. and Cameron, G.T. (2006) 'Corporate crisis planning: tensions, issues, and contradictions', Journal of Communication Management, Vol. 10, No. 4, pp.371-389.

Parmenter, D. (2015) Key Performance Indicators: Developing, Implementing, and Using Winning KPIs, John Wiley \& Sons, Hoboken, New Jersey.

Paton, P.R.A. and McCalman, J. (2008) Change Management: A Guide to Effective Implementation, Sage, Thousand Oaks.

Pavarani, E. (2006) L'equilibrio finanziario, McGraw-Hill, Milan.

Pearce, J.A. and Robbins, D.K. (2008) 'Strategic transformation as the essential last step in the process of business turnaround', Business Horizons, Vol. 51, No. 2, pp.121-130.

Pearson, C.M. and Clair, J.A. (1998) 'Reframing crisis management', Academy of Management Review, Vol. 23, No. 1, pp.59-76. 
Pearson, C.M. and Mitroff, I.I. (1993) 'From crisis prone to crisis prepared: a framework for crisis management', The Executive, Vol. 7, No. 1, pp.48-59.

Phelps, N.L. (1986) 'Setting up a crisis recovery plan', Journal of Business Strategy, Vol. 6, No. 4, pp.5-10.

Postma, T.J.B.M. and Liebl, F. (2005) 'How to improve scenario analysis as a strategic management tool?', Technological Forecasting and Social Change, Vol. 72, No. 2, pp.161173.

Preble, J.F. (1997) 'Integrating the crisis management perspective into the strategic management process', Journal of Management Studies, Vol. 34, No. 5, pp.769-791.

Rappaport, A. (1998) Creating Shareholder Value. A Guide for Managers and Investors, The Free Press, New York.

Rasheed, H.S. (2005) 'Turnaround strategies for declining small business: the effects of performance and resources', Journal of Developmental Entrepreneurship, Vol. 14, No. 3, pp.239-252.

Rashid, Z.A., Sambasivan M. and Rahman, A.A. (2004) 'The influence of organizational culture on attitudes toward organizational change', Leadership \& Organization Development Journal, Vol. 25, No. 2, pp.161-179.

Rauh, J.D. and Sufi, A. (2010) 'Capital structure and debt structure', The Review of Financial Studies, Vol. 23, No. 12, pp.4242-4280.

Reina, R. (2003) Gestione del personale e cambiamento organizzativo nell'amministrazione pubblica, Rubbettino, Soveria Mannelli.

Sahebjamnia, N., Torabi, S.A. and Mansouri, S.A. (2015) 'Integrated business continuity and disaster recovery planning: towards organizational resilience', European Journal of Operational Research, Vol. 242, No. 1, pp.261-273.

Samonas, M. (2015) Financial Forecasting, Analysis and Modelling: A Framework for Long-Term Forecasting, John Wiley \& Sons, Chichester, West Sussex.

Sapriel, C. (2003) 'Effective crisis management: tools and best practice for the new millennium', Journal of Communication Management, Vol. 7, No. 4, pp.348-355.

Schneider, B., Brief, A.P. and Guzzo, R.A. (1996) 'Creating a climate and culture for sustainable organizational change', Organizational Dynamics, Vol. 24, No. 4, pp.7-19.

Slatter, S. and Lovett, D. (1999) Corporate Recovery: Managing Companies in Distress, Beard Books, Washington, D.C.

Sloan, A.P. (1964) My Years with General Motors, Doubleday, Garden City, NY.

Stohs, M.H. and Mauer, D.C. (1996) 'The determinants of corporate debt maturity structure', The Journal of Business, Vol. 69, No. 3, pp.279-312.

Sudarsanam, S. and Lai, J. (2001) 'Corporate financial distress and turnaround strategies: an empirical analysis', British Journal of Management, Vol. 12, No. 3, pp.183-199.

Sweetser, K.D. and Metzgar, E. (2007) 'Communicating during crisis: use of blogs as a relationship management tool', Public Relations Review, Vol. 33, No. 3, pp.340-342.

Tiscini, R. (2014) Economia della crisi d'impresa, Egea, Milan.

Titman, S. and Wessels, R. (1988) 'The determinants of capital structure choice', The Journal of Finance, Vol. 43, No. 1, pp.1-19.

Tocquigny, R. and Butcher, A. (2012) When Core Values are Strategic: How the Basic Values of Procter \& Gamble transformed leadership at Fortune 500 Companies, FT Press, New Jersey.

Todnem, R. (2005) 'Organisational change management: a critical review', Journal of Change Management, Vol. 5, No. 4, pp.369-380.

Trequattrini, R. (2004) Processo decisionale e valore delle aziende. Un approccio integrato, Giappichelli, Turin. 
Tron, A. (2013) 'Il piano di risanamento quale strumento risolutivo della crisi', in Ambrosini, S. et al. (Eds): Crisi d'impresa e restructuring. Aspetti economico-aziendali, giuridici e fiscali alla luce delle prime applicazioni e interpretazioni delle norme introdotte dalla legge 134/2012, Il Sole 24 Ore, Milano.

Von Thadden, E.L., Berglöf, E. and Roland, G. (2010) 'The design of corporate debt structure and bankruptcy', The Review of Financial Studies, No. 7, pp.2648-2679.

Waisman, S.Y. and Lucas, J.W. (2008) 'The role and retention of the chief restructuring officer', in PricewaterhouseCoopers and Morgan Stanley (Eds): The Americas Restructuring and Insolvency Guide 2008/2009, Globe White Page, London.

Wang, J. (2008) 'Developing organizational learning capacity in crisis management', Advances in Developing Human Resources, Vol. 10, No. 3, pp.425-445.

Wegmann, G. (2000) 'Les tableaux de bord stratégiques: analyse comparative d'un modèle nordaméricain et d'un modèle suédois', Gestion 2000, Vol. 17, No. 1, pp.19-35.

Westover, J.H. (2010) 'Managing organizational change: change agent strategies and techniques to successfully managing the dynamics of stability and change in organizations', International Journal of Management and Innovation, Vol. 2, No. 1, pp.45-50.

Williams, D.E. and Olaniran, B.A. (1998) 'Expanding the crisis planning function: introducing elements of risk communication to crisis communication practice', Public Relations Review, Vol. 24, No. 3, pp.387-400.

Wood, P.R. (2007) Principles of International Insolvency, Sweet \& Maxwell, London.

Zanoni, A.B. (2009) Accounting for Goodwill, Routledge, New York.

Zanoni, A.B. and Campedelli, B. (2007) Economia dell'impresa: governo e controllo, Il Mulino, Bologna.

\section{Notes}

1 "Principi di Redazione dei Piani di Risanamento" it is a document that has been developed for nearly two years by a group of about 40 academics, professionals and business consultants and that has been promoted and approved by ANDAF (Associazione Nazionale Direttori Amministrativi e Finanziari - National Association of Administrative and Financial Directors), AIDEA (Accademia Italiana di Economia Aziendale - Italian Academy of Business Administration), APRI (Associazione Professionisti per il Risanamento d'Impresa Professional Association for Business Recovery), OCRI (Osservatorio Crisi a Risanamento d'Impresa dell'Università di Bergamo - University of Bergamo Business Recovery Crisis Observatory), AIAF (Associazione Italiana Analisti Finanziari - Italian Association of Financial Analysts), and CNDCEC (Consiglio Nazionale Dottori Commercialisti e Esperti Contabili - National Council of Chartered Accountants and Accounting Experts). 